\title{
Subtropical Arctic Ocean temperatures during the Palaeocene/Eocene thermal maximum
}

\author{
Appy Sluijs ${ }^{1 \star}$, Stefan Schouten ${ }^{2 \star}$, Mark Pagani ${ }^{3}$, Martijn Woltering ${ }^{2}$, Henk Brinkhuis ${ }^{1}$, \\ Jaap S. Sinninghe Damsté ${ }^{2,4}$, Gerald R. Dickens ${ }^{5}$, Matthew Huber ${ }^{6}$, Gert-Jan Reichart ${ }^{4}$, Ruediger Stein ${ }^{7}$, \\ Jens Matthiessen ${ }^{7}$, Lucas J. Lourens ${ }^{4}$, Nikolai Pedentchouk ${ }^{3}$, Jan Backman ${ }^{8}$, Kathryn Moran ${ }^{9}$ \\ $\&$ the Expedition 302 Scientists $\dagger$
}

The Palaeocene/Eocene thermal maximum, $\sim 55$ million years ago, was a brief period of widespread, extreme climatic warming ${ }^{1-3}$, that was associated with massive atmospheric greenhouse gas input $^{4}$. Although aspects of the resulting environmental changes are well documented at low latitudes, no data were available to quantify simultaneous changes in the Arctic region. Here we identify the Palaeocene/Eocene thermal maximum in a marine sedimentary sequence obtained during the Arctic Coring Expedition $^{5}$. We show that sea surface temperatures near the North Pole increased from $\sim 18^{\circ} \mathrm{C}$ to over $23^{\circ} \mathrm{C}$ during this event. Such warm values imply the absence of ice and thus exclude the influence of ice-albedo feedbacks on this Arctic warming. At the same time, sea level rose while anoxic and euxinic conditions developed in the ocean's bottom waters and photic zone, respectively. Increasing temperature and sea level match expectations based on palaeoclimate model simulations $s^{6}$, but the absolute polar temperatures that we derive before, during and after the event are more than $10^{\circ} \mathrm{C}$ warmer than those model-predicted. This suggests that higher-than-modern greenhouse gas concentrations must have operated in conjunction with other feedback mechanisms-perhaps polar stratospheric clouds ${ }^{7}$ or hurricane-induced ocean mixing ${ }^{8}$ - to amplify early Palaeogene polar temperatures.

Stable carbon isotope $\left(\delta^{13} \mathrm{C}\right)$ records of carbonate and organic carbon from numerous sites show a prominent negative carbon isotope excursion across the Palaeocene/Eocene thermal maximum $(\text { PETM })^{2,9}$. The carbon isotope excursion is expressed as a $>2.5 \%$ drop in $\delta^{13} \mathrm{C}$, which signifies an input of at least $1.5 \times 10^{18} \mathrm{~g}$ of ${ }^{13} \mathrm{C}$-depleted carbon, somewhat analogous in magnitude and composition to current and expected fossil fuel emissions. The PETM captures $\sim 200 \mathrm{kyr}$ (ref. 10) and is associated with profound environmental changes that are well-documented at low- to mid-latitudes $\left(<60^{\circ}\right)$, including a $4-8{ }^{\circ} \mathrm{C}$ temperature rise of surface and deep ocean waters ${ }^{1-3}$ and major terrestrial and marine biotic changes ${ }^{11-13}$. Terrestrial mammal turnovers are consistent with mass migrations across Arctic regions resulting from high-latitude warming ${ }^{14}$, but no Arctic data have existed to evaluate this hypothesis.

The Integrated Ocean Drilling Program Expedition (IODP) 302 (or the Arctic Coring Expedition) recently recovered a Palaeogene marine sedimentary record from Hole $4 \mathrm{~A}\left(\sim 87^{\circ} 52.00^{\prime} \mathrm{N}\right.$; $136^{\circ} 10.64^{\prime} \mathrm{E} ; 1,288 \mathrm{~m}$ water depth), on the Lomonosov ridge in the central Arctic Ocean ${ }^{5}$. This ridge represents a fragment of continental crust that rifted from the Eurasian shelf margin at high latitudes $\left(>85^{\circ}\right.$; Fig. 1$)$ during the latest part of the Palaeocene epoch and subsided to present depths after the Palaeocene. Upper Palaeocene and Lower Eocene sediments between approximately 406 and $263 \mathrm{~m}$ composite depth below sea floor (m.c.d.) at Hole 4A consist of organic-rich ( $\sim 2 \%$ total organic carbon (TOC) by mass on average) siliciclastic claystone ${ }^{5}$. Shipboard observations showed that this interval is barren of calcareous and siliceous microfossils but yields rich assemblages of palynomorphs, notably organic-walled dinoflagellate cysts (dinocysts) and terrestrial pollen and spores ${ }^{5}$.

The PETM was identified from the top of Core $32 \mathrm{X}$ to within Core

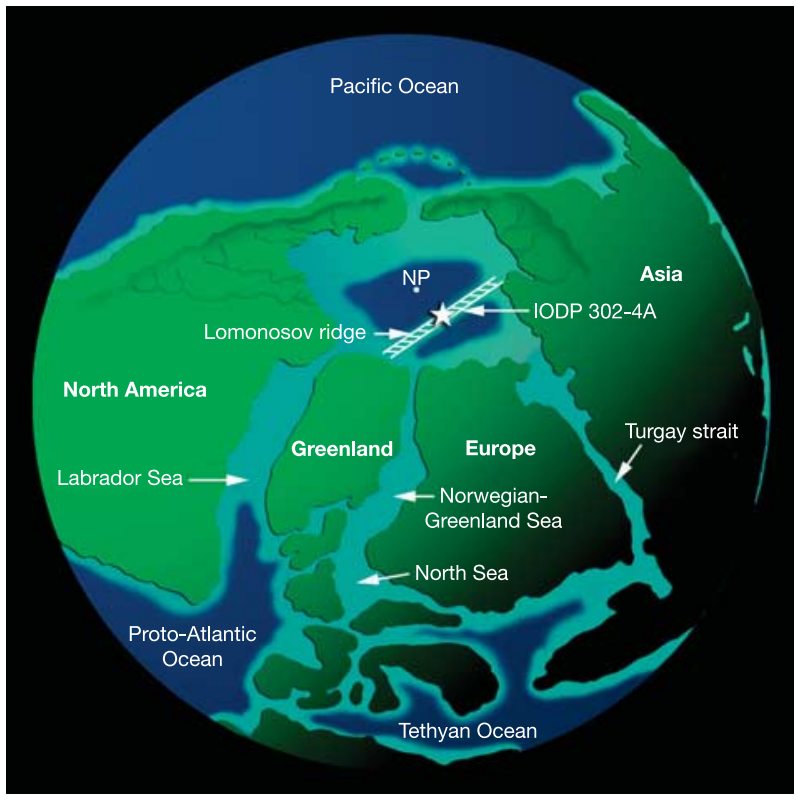

Figure 1 | Location of IODP Hole 302-4A within the palaeogeographic reconstruction of the Arctic Basin at late Palaeocene-early Eocene times. The figure is modified from ref. 24. NP, North Pole.

${ }^{1}$ Palaeoecology, Institute of Environmental Biology, Utrecht University, Laboratory of Palaeobotany and Palynology, Budapestlaan 4, 3584 CD Utrecht, The Netherlands. ${ }^{2}$ Royal Netherlands Institute for Sea Research (NIOZ), Department of Marine Biogeochemistry and Toxicology, PO Box 59,1790 AB, Den Burg, Texel, The Netherlands. ${ }^{3}$ Department of Geology and Geophysics, Yale University, PO Box 208109, New Haven, Connecticut 06520, USA. ${ }^{4}$ Department of Earth Sciences, Utrecht University, Budapestlaan 4, 3584 CD Utrecht, The Netherlands. ${ }^{5}$ Department of Earth Sciences, Rice University, 6100 Main Street, Houston, Texas 77005, USA. ${ }^{6}$ Earth and Atmospheric Sciences Department and the Purdue Climate Change Research Center, Purdue University, 550 Stadium Mall Drive, West Lafayette, Indiana 47906, USA. ${ }^{7}$ Alfred-Wegener-Institute for Polar and Marine Research, Columbusstrasse, 27568 Bremerhaven, Germany. ${ }^{8}$ Department of Geology and Geochemistry, Stockholm University, Stockholm, SE-106 91, Sweden. ${ }^{9}$ University of

Rhode Island, Bay Campus, Narragansett, Rhode Island 02882, USA.

*These authors contributed equally to this work.

$\dagger$ A list of authors and affiliations appears at the end of the paper. 
29X ( 387-378.5 m.c.d.) by the occurrence of the dinocyst species Apectodinium augustum, which is diagnostic of the PETM ${ }^{15}$ (Fig. 2; Supplementary Fig. S-1a). The lower bound is somewhat problematic, though, because the upper $50 \mathrm{~cm}$ of Core $32 \mathrm{X}$ has been disturbed by drilling and various proxies suggests that the sediment from this interval represents a mixture of uppermost Palaeocene and PETM material ${ }^{16}$. Moreover, only $55 \mathrm{~cm}$ of section was recovered of the critical Core 31X, which has an uncertain stratigraphic position relative to Cores $30 \mathrm{X}$ and $32 \mathrm{X}$ (see error bars in Fig. 2 and Supplementary Information). Stable carbon isotopes of bulk organic carbon $\left(\delta^{13} \mathrm{C}_{\mathrm{TOC}}\right)$ show a prominent $\sim 6 \%$ drop between the top of Core $32 X$ (388 m.c.d.) and $31 X$ ( $\sim 386$ m.c.d.), apart from one value from the disturbed zone, followed by a gradual recovery through Cores $30 \mathrm{X}$ and $29 \mathrm{X}$ to $\sim 378.5$ m.c.d. (Fig. 2). The $\delta^{13} \mathrm{C}_{\mathrm{TOC}}$ pattern is generally reproduced in the carbon isotope record of the $\mathrm{C}_{27}$ and $\mathrm{C}_{29}$ $n$-alkanes, which are biomarkers derived from the leaf waxes of terrestrial higher plants ${ }^{16}$. Despite the core gaps, the magnitude and shape of the $\delta^{13} \mathrm{C}_{\mathrm{TOC}}$ excursion resembles other shallow marine PETM sections, such as Doel in Belgium ${ }^{17}$, confidently correlating this interval to the Palaeocene/Eocene boundary event.

Before the PETM, Apectodinium was a subtropical dinoflagellate restricted to low latitudes ${ }^{11,15}$. Thus, the sudden influx of Apectodinium spp. dinocysts across the PETM at Hole 4A (Fig. 2) suggests a substantial rise in Arctic sea surface temperature (SST) to subtropical or tropical levels. Angiosperm pollen becomes more abundant at the expense of spores and gymnosperm pollen (Fig. 2), suggesting an expanded growing season. The lack of calcareous microfossils prohibits the use of the common techniques for quantifying past SSTs. Instead, we employed the newly developed palaeothermometer $\mathrm{TEX}_{86}{ }^{\prime}$ (see Supplementary Information), which is based on the distribution of crenarchaeotal membrane lipids ${ }^{18}$. This distribution is independent of surface water parameters such as nutrient availability or salinity ${ }^{18,19}$, and shows a highly significant linear correlation with present-day mean annual SST in the range of 10 to $28^{\circ} \mathrm{C}$ (Supplementary Fig. S-2B). Because the export of crenarchaeotal lipids to the sea floor predominantly occurs during the season with highest phytoplankton productivity, which in the Arctic Ocean is summer, our $\mathrm{TEX}_{86}{ }^{\prime}$ record is probably skewed towards summer temperatures (see also Supplementary Information).

Arctic SSTs rose from $\sim 18{ }^{\circ} \mathrm{C}$ in the latest Palaeocene, to over $23^{\circ} \mathrm{C}$ during the PETM, and subsequently decreased to $\sim 17^{\circ} \mathrm{C}$ by the end of the event (Fig. 2). Background SSTs from the latest Palaeocene and early Eocene are generally consistent with the few other proxy data estimates from Arctic locations with late Cretaceous and early Palaeogene strata ${ }^{20-22}$. The significantly lower terrestrial temperature estimates from Ellesmere Island at $73^{\circ} \mathrm{N}$ palaeolatitude ${ }^{23}$ are derived from upper Lower Eocene strata and are similar to $\mathrm{TEX}_{86}$-derived SSTs in the Arctic Ocean for that time period ${ }^{24}$; these estimates are thus not in disagreement with our data. Maximum SSTs coincide with minimum $\delta^{13} \mathrm{C}$ values during the PETM, while the cooling trend mirrors the recovery pattern in $\delta^{13} \mathrm{C}$ and a decrease of angiosperm pollen.

Several lines of evidence (Fig. 2) suggest that the location of Hole 4A was proximal to the coast and strongly influenced by fluvial inputs in the latest Palaeocene. For example, palynomorph assemblages from upper Palaeocene strata are dominated by terrestrial spores and pollen ( 90\%). Those samples with sufficient dinocysts yield abundant Senegalinium spp. and Cerodinium spp. (Supplementary Fig. S-1), which probably come from dinoflagellates that tolerated low surfacewater salinities ${ }^{24}$ and required nutrient-rich conditions ${ }^{25}$. Sediments from this interval also contain abundant amorphous organic matter, presumably of terrestrial origin. Moreover, values of the Branched and Isoprenoid Tetraether (BIT) index-a measure for the amount of river-derived terrestrial organic matter relative to marine organic matter ${ }^{26}$-are relatively high.

In contrast to uppermost Palaeocene sediments, palynomorph assemblages from the PETM interval are characterized by abundant dinocysts (60\%) and substantially lower BIT indices (Fig. 2), indicating a relative decrease of riverine-derived organic carbon. Also, the increase in the Rock Eval hydrogen index suggests a relative increase in aquatic versus terrestrial organic matter (Supplementary Fig. S-3A). We attribute the enhanced influence of marine conditions during the

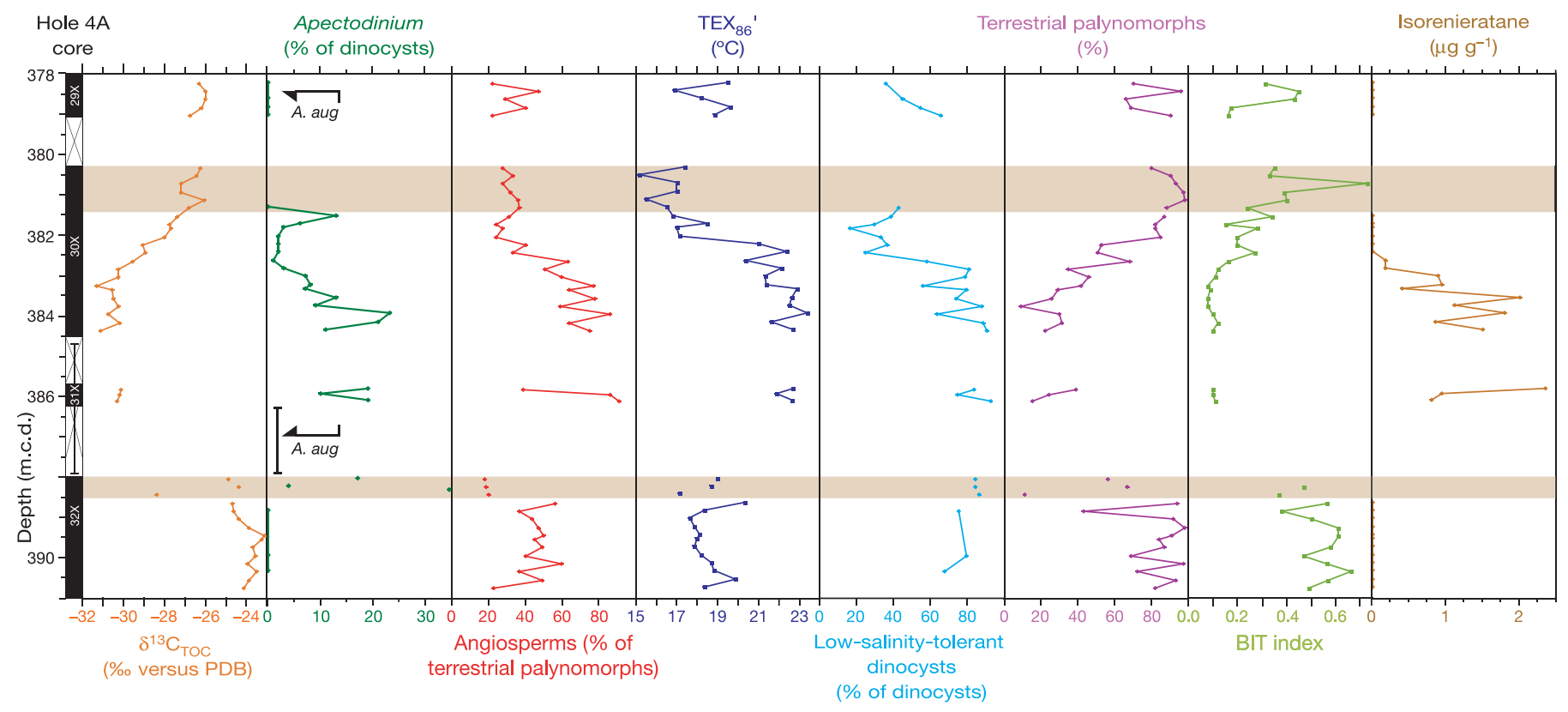

Figure 2 | Core recovery and palynological and geochemical results across the PETM of IODP Hole 302-4A. Core $31 \mathrm{X}$ was plotted $100 \mathrm{~cm}$ lower than m.c.d. ${ }^{5}$ for illustration purposes. Error bars connected to Core $31 \mathrm{X}$ in the recovery column indicate the uncertainty of its stratigraphic position (see Supplementary Information). Orange bars indicate intervals affected by drilling disturbance. Stable carbon isotopes are expressed relative to the
PeeDee Belemnite standard. Low-salinity-tolerant dinocysts comprise Senegalinium spp., Cerodinium spp., and Polysphaeridium spp., while Membranosphaera spp., Spiniferites ramosus complex, and Areoligera-Glaphyrocysta cpx. represent the typical normal marine species ${ }^{25}$ (Supplementary Fig. S-1). Arrows and A. aug indicate the first and last occurrences of dinocyst Apectodinium augustum. 
PETM to a sea level rise, an interpretation consistent with evidence from other neritic locations ${ }^{27}$. The gradual return to more terrestrial influence later in the event probably results from subsequent regression. Despite the transgression, low-salinity-tolerant dinocysts remain dominant (Fig. 2), showing that brackish surface waters persisted during the PETM. If the earliest Palaeogene greenhouse world was continental-ice-free, a mechanism for the sea-level rise may comprise the $\sim 5 \mathrm{~m}$ thermal expansion of sea water expected from a $5-8{ }^{\circ} \mathrm{C}$ (refs 2,3 ) increase in deep ocean temperatures.

The occurrence of laminated sediments from the onset of the PETM (although hardly visible in Core 31X due to its disturbed state) up to 382.5 m.c.d., and the absence of benthic foraminiferal linings (Supplementary Fig. S-3A) suggest that bottom waters became anoxic during the PETM. Within the laminated interval, derivatives of the characteristic pigment isorenieratene are recorded in concentrations of up to $2 \mathrm{\mu gg}^{-1}$ sediment; they are below the detection limit outside this interval (Fig. 2; Supplementary Fig. S-3). These compounds are derived from the brown strain of photosynthetic green sulphur bacteria, which requires euxinic (anoxic and sulphidic) conditions to thrive ${ }^{28}$. Accordingly, at the PETM photic zone euxinia developed at the drill site coincident with bottom water anoxia, which gradually disappeared during the recovery of SST and $\delta{ }^{13} \mathrm{C}$ excursion (Fig. 2).

We can exclude selective preservation as a mechanism to explain the marked changes in organic biomarkers and palynomorph assemblages that occur in coincidence with water column anoxia. First, the preservation of organic matter is also excellent outside the laminated interval $(>2 \%$ TOC on average; Supplementary Fig. S-3A) and second, most of our proxies compare the relative abundance of structurally similar organic compounds that are equally susceptible to oxidation (see Supplementary Information).

The euxinic conditions were potentially caused by several factors. For example, increased freshwater input, greater nutrient load and warmer temperatures would all conspire to reduce dissolved $\mathrm{O}_{2}$ in the water column. However, given the shallow water depth of the site, an important factor was probably intense stratification due to the influence of a brackish surface-water lid. Although several mechanisms could drive such stratification, given that low-salinity-tolerant dinocysts remain dominant despite the more distal position of the site, and given the data presented in a companion paper ${ }^{16}$, the simplest explanation is that decreased mixing resulted from increased SSTs and enhanced fluvial runoff, with the latter also supplying extra nutrients to increase production and saturate photic zone respiration. The termination of euxinic conditions coincides with increasing surface salinities ${ }^{16}$ (Fig. 2) and cooling, suggesting an increase of mixing with more-saline deeper waters.

Even if we assume that our $\mathrm{TEX}_{86}{ }^{\prime}$ temperatures represent summer values (see Supplementary Information), palaeoclimate models simulating the early Palaeogene world with 2,000 p.p.m.v. of $\mathrm{CO}_{2}$ in the atmosphere ${ }^{6}$ underestimate Arctic Ocean summer SSTs by at least $15^{\circ} \mathrm{C}$ for the PETM and $10^{\circ} \mathrm{C}$ for the surrounding late Palaeocene and early Eocene. This discrepancy may be even larger because the initial part of the PETM, and potentially also the strata formed under maximum temperatures, were possibly not recovered (Fig. 2). On the other hand, the magnitude of the carbon isotope excursion is comparable to previous studies and peak PETM temperatures lagged the onset of the carbon isotope excursion by $\sim 40 \mathrm{kyr}$ (ref. 1), indicating that optimum Arctic SSTs are probably covered in our record.

The models consistently predict pole-to-Equator temperature gradients of $\sim 30^{\circ} \mathrm{C}$ (ref. 29). Such gradients represent significant overestimates because they would imply unrealistically warm tropical SSTs considering our polar temperatures. The high polar temperatures and reduced pole-to-Equator temperature gradients cannot be explained by invoking even greater greenhouse gas concentrations because this would elevate tropical SSTs, which in existing model predictions already match or exceed those determined from proxy records at low-latitude locations ${ }^{6}$. Also, ocean heat transport is unlikely to be the cause because this requires a threefold increase, which cannot be simulated in the current generation of fully coupled ocean-atmosphere climate models ${ }^{29}$. Similarly, atmospheric general circulation models do not support strong enough positive feedbacks in atmospheric heat transport ${ }^{30}$. Consequently, we surmise that physical processes that are not yet incorporated in the models operated in conjunction with high greenhouse gas concentrations to enhance polar warmth and reduce the pole-to-Equator temperature gradient during the early Palaeogene. These processes could include high-latitude warming and tropical cooling through the enhancement of polar stratospheric clouds ${ }^{7}$, and hurricane-induced ocean mixing $^{8}$, respectively.

With latest Palaeocene SSTs of $18^{\circ} \mathrm{C}$ it is not likely that ice was present in the Arctic. This implies that the PETM at Hole 4A allows us to examine the Arctic environment and the nature of polar amplification during a time of massive greenhouse gas emissions and extreme global warming in the absence of ice-albedo feedbacks. Interestingly, polar amplification of temperature rise at the PETM appears to have been minor (Fig. 2; refs 1-3), suggesting that the strengthening of the mechanism that caused above early Palaeogene polar temperature amplification was small at the PETM. Our extremely warm polar temperatures indicate that, despite much recent progress, feedbacks responsible for early Palaeogene mid- to high-latitude warmth remain poorly understood and are not implemented in existing climate models.

\section{METHODS}

Palynology. Sediments were oven-dried at $60^{\circ} \mathrm{C}$. To $\sim 2 \mathrm{~g}$ of sediment, a known amount of Lycopodium spores were added, after which the sample was treated with $30 \% \mathrm{HCl}$ and twice with $30 \% \mathrm{HF}$ for carbonate and silicate removal, respectively. After sieving over a $15-\mu \mathrm{m}$ nylon mesh sieve, residues were analysed at $500 \times$ magnification until a minimum of 200 dinocysts had been recorded per sample. Absolute quantitative numbers were calculated using the relative number of Lycopodium.

Organic geochemistry. Powdered and freeze-dried sediments were analysed for $\%$ TOC and $\delta{ }^{13} \mathrm{C}_{\text {TOC }}$ with a Fison NA 1500 CNS analyser, connected to a Finnigan Delta Plus mass spectrometer. Analytical precision and accuracy were determined by replicate analyses and by comparison with international and in-house standards, and were better than $0.1 \%$ and $0.1 \%$ for $\%$ TOC and $\delta^{13} \mathrm{C}_{\mathrm{TOC}}$, respectively.

Powdered and freeze-dried sediments (1-3 g dry mass) were extracted with dichloromethane (DCM)/methanol (2:1) by using the Dionex accelerated solvent extraction technique. The extracts were separated by $\mathrm{Al}_{2} \mathrm{O}_{3}$ column chromatography using hexane/DCM (9:1) and DCM/methanol (1:1) to yield the apolar and polar fractions, respectively. The apolar fractions were analysed for isorenieratene derivatives by gas chromatography and gas chromatography/mass spectrometry, while the polar fractions were analysed for tetraether lipids and used to calculate $\mathrm{TEX}_{86}{ }^{\prime}$ (see Supplementary Information; reproducibility was within $\sim 1^{\circ} \mathrm{C}$ ) and BIT (see ref. 26 for method description) indices.

\section{Received 7 July 2005; accepted 21 February 2006.}

1. Zachos, J. C. et al. A transient rise in tropical sea surface temperature during the Paleocene-Eocene thermal maximum. Science 302, 1151-1154 (2003).

2. Kennett, J. P. \& Stott, L. D. Abrupt deep-sea warming, palaeoceanographic changes and benthic extinctions at the end of the Palaeocene. Nature 353, 225-229 (1991)

3. Tripati, A. \& Elderfield, H. Deep-sea temperature and circulation changes at the Paleocene-Eocene thermal maximum. Science 308, 1894-1898 (2005)

4. Dickens, G. R., O'Neil, J. R., Rea, D. K. \& Owen, R. M. Dissociation of oceanic methane hydrate as a cause of the carbon isotope excursion at the end of the Paleocene. Paleoceanography 10, 965-971 (1995).

5. Backman, J., Moran, K., McInroy, D. B., Mayer, L. A. \& the Expedition 302 Scientists. Arctic Coring Expedition (ACEX). Proc. ODP 302 I/doi:10.2204/ iodp.proc.302.2006 (Integrated Ocean Drilling Program Management International, College Station, Texas, 2006).

6. Shellito, C. J., Sloan, L. C. \& Huber, M. Climate model sensitivity to atmospheric $\mathrm{CO}_{2}$ levels in the Early-Middle Paleogene. Palaeogeogr. Palaeoclimatol. Palaeoecol. 193, 113-123 (2003).

7. Sloan, L. C. \& Pollard, D. Polar stratospheric clouds: A high latitude warming mechanism in an ancient greenhouse world. Geophys. Res. Lett. 25, 3517-3520 (1998). 
8. Emanuel, K., DesAutels, C., Holloway, C. \& Korty, R. Environmental Control of Tropical Cyclone Intensity. J. Atmos. Sci. 61, 843-858 (2004).

9. Koch, P. L., Zachos, J. C. \& Gingerich, P. D. Correlation between isotope records in marine and continental carbon reservoirs near the Palaeocene/ Eocene boundary. Nature 358, 319-322 (1992).

10. Röhl, U., Bralower, T. J., Norris, G. \& Wefer, G. A new chronology for the late Paleocene thermal maximum and its environmental implications. Geology 28, 927-930 (2000).

11. Crouch, E. M. et al. Global dinoflagellate event associated with the late Paleocene thermal maximum. Geology 29, 315-318 (2001).

12. Thomas, E. \& Shackleton, N. J. in Correlation of the Early Paleogene in Northwestern Europe (eds Knox, R. W. O. B., Corfield, R. M. \& Dunay, R. E.) 401-441 (Geological Society of London Special Publication 101, 1996).

13. Wing, S. L. in Late Paleocene-early Eocene Climatic and Biotic Events in the Marine and Terrestrial Records (eds Aubry, M.-P., Lucas, S. G. \& Berggren, W. A.) 380-400 (Columbia Univ. Press, New York, 1998).

14. Bowen, G. J. et al. Mammalian dispersal at the Paleocene/Eocene boundary. Science 295, 2062-2065 (2002).

15. Bujak, J. P. \& Brinkhuis, H. in Late Paleocene-early Eocene Climatic and Biotic Events in the Marine and Terrestrial Records (eds Aubry, M.-P., Lucas, S. G. \& Berggren, W. A.) 277-295 (Columbia Univ. Press, New York, 1998).

16. Pagani, M. et al. Arctic's hydrology during global warming at the Palaeocene/Eocene thermal maximum. Nature (submitted).

17. Steurbaut, E. et al. in Causes and Consequences of Globally Warm Climates in the Early Paleogene (eds Wing, S. L., Gingerich, P., Schmitz, B. \& Thomas, E.) 291-317 (Geological Society of America Special Paper 369, Boulder, Colorado, 2003).

18. Schouten, S., Hopmans, E. C., Schefuß, E. \& Sinninghe Damsté, J. S Distributional variations in marine crenarchaeotal membrane lipids: a new tool for reconstructing ancient sea water temperatures? Earth Planet. Sci. Lett. 204, 265-274 (2002).

19. Wuchter, C., Schouten, S., Coolen, M. J. L. \& Sinninghe Damsté, J. S. Temperature-dependent variation in the distribution of tetraether membrane lipids of marine Crenarchaeota: Implications for TEX 86 paleothermometry. Paleoceanography 19, doi:10.1029/2004PA001041 (2004).

20. Markwick, P. J. Fossil crocodilians as indicators of Late Cretaceous and Cenozoic climates: Implications for using palaeontological data in reconstructing palaeoclimate. Palaeogeogr. Palaeoclimatol. Palaeoecol. 137 205-271 (1998)

21. Tripati, A., Zachos, J., Marincovich, L. Jr \& Bice, K. Late Paleocene Arctic coastal climate inferred from molluscan stable and radiogenic isotope ratios. Palaeogeogr. Palaeoclimatol. Palaeoecol. 170, 101-113 (2001).

22. Jenkyns, H. C., Forster, A., Schouten, S. \& Sinninghe Damsté, J. S. High temperatures in the Late Cretaceous Arctic Ocean. Nature 432, 888-892 (2004).

23. Fricke, H. C. \& Wing, S. L. Oxygen isotope and paleobotanical estimates of temperature and $\delta^{18} \mathrm{O}$-latitude gradients over North America during the early Eocene. Am. J. Sci. 304, 612-635 (2004).

24. Brinkhuis, $H$. et al. Episodic fresh surface waters in the Eocene Arctic Ocean. Nature doi:10.1038/nature04692 (this issue).

25. Sluijs, A., Pross, J. \& Brinkhuis, H. From greenhouse to icehouse; organic-walled dinoflagellate cysts as paleoenvironmental indicators in the Paleogene. Earth Sci. Rev. 68, 281-315 (2005).

26. Hopmans, E. C. et al. A novel proxy for terrestrial organic matter in sediments based on branched and isoprenoid tetraether lipids. Earth Planet. Sci. Lett. 224 107-116 (2004)

27. Speijer, R. P. \& Morsi, A.-M. M. Ostracode turnover and sea-level changes associated with the Paleocene-Eocene thermal maximum. Geology 30, 23-26 (2002).

28. Sinninghe-Damsté, J. S., Wakeham, S. G., Kohnen, M. E. L., Hayes, J. M. \& De Leeuw, J. W. A 6,000-year sedimentary molecular record of chemocline excursions in the Black Sea. Nature 362, 827-829 (1993).

29. Huber, M., Sloan, L. C. \& Shellito, C. J. in Causes and Consequences of Globally Warm Climates in the Early Palaeogene (eds Wing, S. L., Gingerich, P. D., Schmitz, B. \& Thomas, E.) 25-47 (Geological Society of America Special Paper 369, Boulder, Colorado, 2003).

30. Caballero, R. \& Langen, P. L. The dynamic range of poleward energy transport in an atmospheric general circulation model. Geophys. Res. Lett. 32, doi: 10.1029/2004GL021581 (2005).

Supplementary Information is linked to the online version of the paper at www.nature.com/nature.

Acknowledgements A.S. thanks the Utrecht Biogeology Centre for funding. H.B. thanks the Netherlands Organization for Scientific Research, and Utrecht University for enabling participation in the ACEX expedition. M.H. thanks the Purdue Climate Change Research Center, ITaP and the Purdue Research Foundation for their continued support. This research used samples and data provided by the IODP. We thank L. Bik, J. van Tongeren, N. Welters and A. van Dijk for technical support, and C. E. Stickley for discussions.

Author Contributions A.S. and H.B. carried out the palynology, A.S. \& G.-J.R. the $\delta^{13} C_{\text {TOC }}$ S.S., M.W. and J.S.S.D. the TEX 86 ', BIT and isorenieratane analyses. R.S. generated the hydrogen index data. J.B. and K.M. were the co-chiefs of the ACEX expedition. N.P., J.M and the Expedition 302 Scientists were involved in generating shipboard and shore-based ACEX data. A.S., S.S., M.P., H.B., J.S.S.D., G.R.D., M.H. and L.J.L. contributed to interpreting the data and writing the paper.

Author Information Reprints and permissions information is available at npg.nature.com/reprintsandpermissions. The authors declare no competing financial interests. Correspondence and requests for materials should be addressed to A.S. (a.sluijs@bio.uu.nl) or S.S. (schouten@nioz.nl)

Expedition 302 Scientists (those not listed above): Steve Clemens ${ }^{1}$, Thomas Cronin ${ }^{2}$, Frédérique Eynaud ${ }^{3}$, Jérôme Gattacceca ${ }^{4}$, Martin Jakobsson ${ }^{5}$, Ric Jordan ${ }^{6}$, Michael Kaminski ${ }^{7}$, John King ${ }^{8}$, Nalân Koc ${ }^{9}$, Nahysa C. Martinez ${ }^{10}$, David McInroy ${ }^{11}$, Theodore C. Moore Jr ${ }^{12}$, Matthew O’Regan ${ }^{8}$, Jonaotaro Onodera ${ }^{13}$, Heiko Pälike ${ }^{14}$, Brice Rea ${ }^{15}$, Domenico Rio ${ }^{16}$, Tatsuhiko Sakamoto ${ }^{17}$, David C. Smith ${ }^{8}$, Kristen E. K. St John ${ }^{18}$, Itsuki Suto ${ }^{19}$, Noritoshi Suzuki ${ }^{20}$, Kozo Takahashi ${ }^{13}$, Mahito Watanabe $^{21}$ \& Masanobu Yamamoto ${ }^{22}$

${ }^{1}$ Geological Sciences, Brown University, 324 Brook Street, PO Box 1846, Providence, Rhode Island 02912-1846, USA. ${ }^{2}$ US Geological Survey, Eastern Earth Surface Processes Team, 926A USGS National Center, Reston, Virginia 20192, USA. ${ }^{3}$ Department de Géologie et Océanographie, Université Bordeaux 1, Avenue des facultés, c/o Bernei Housen, 33405 Talence Cedex, France. ${ }^{4}$ Department of Geophysics, CEREGE (CNRS)/University of Aix-Marseille 3, BP 80, 13545 Aix-en-Provence Cedex 4, France. ${ }^{5}$ Department of Geology and Geochemistry, Stockholm University, 10691 Stockholm, Sweden. ${ }^{6}$ Department of Earth and Environmental Sciences, Faculty of Science, Yamagata University, 1-4-12 Kojirakawa-machi, Yamagata 990-8560, Japan. ${ }^{7}$ Department of Earth Sciences, University College London, Gower Street, London WC1E 6BT, UK. ${ }^{8}$ Graduate School of Oceanography, University of Rhode Island, Narragansett Bay Campus, South Ferry Road, Narragansett, Rhode Island 02882, USA. ${ }^{9}$ Norwegian Polar Institute, Polar Environmental Center, N-9296 Tromsø, Norway. ${ }^{10}$ Department of Earth Sciences, Boston University, 685 Commonwealth Avenue, Boston, Massachusetts 02215, USA. ${ }^{11}$ British Geological Survey, Murchison House, West Mains Road, Edinburgh, EH9 3LA, UK. ${ }^{12}$ Geological Sciences, University of Michigan, Ann Arbor, Michigan 48109-1063, USA. ${ }^{13}$ Department of Earth and Planetary Sciences, Graduate School of Sciences, Kyushu University, Hakozaki 6-10-1, Higashi-ku, Fukuoka 812-8581, Japan. ${ }^{14}$ School of Ocean and Earth Science, University of Southampton, Southampton Oceanography Center, European Way, Southampton SO14 3ZH, UK. ${ }^{15}$ Department of Geography and Environment, School of Geosciences, University of Aberdeen, Elphinstone Road, Aberdeen AB24 3UF, UK. ${ }^{16}$ Department of Geology, Paleontology and Geophysics, University of Padova, Via Giotto 1 I-35137 Padova, Italy. ${ }^{17}$ Institute for Research on Earth Evolution (IFREE), Japan Agency for Marine-Earth Science and Technology (JAMSTEC), Natsushima-cho 2-15, Yokosuka 237-0061, Japan. ${ }^{18}$ Department of Geology and Environmental Science, MSC 7703, James Madison University, Harrisonburg, Virginia 22807, USA. ${ }^{19}$ Institute of Life and Environmental Science, University of Tsukuba, Tennoudai 1-1-1, Tsukuba, Ibaraki 305-8572, Japan. ${ }^{20}$ Institute of Geology and Paleontology, Graduate School of Science, Tohoku University, Aramaki, Aoba, Aoba-ku, Sendai City 980-8578, Japan. ${ }^{21}$ Institute of Geoscience, National Institute of Advanced Industrial Science, and Technology (Geological Survey of Japan) AIST Tsukuba Central 7, Higashi-1-1-1, Tsukuba, Ibaraki 305-8567, Japan. ${ }^{22}$ Graduate School of Environmental Earth Science, Hokkaido University, Kita-10, Nishi-5, Kita-ku, Sapporo 060-0810, Japan 